\title{
LOCALITY AND SOCIAL CAPITAL REVIVAL AS LOCAL DEVELOPMENT ASSETS IN UKRAINE: THE CASE OF RURAL AREAS IN KHMELNYTSKYI REGION
}

\author{
Aleksandra SYNOWIEC \\ Silesian University of Technology, Faculty of Organization and Management; aleksandra.synowiec@polsl.pl, \\ ORCID: 0000-0001-8251-2322
}

Purpose: The aim of this paper is to discuss the issues of localism and social capital revival as important factors of local and regional development of rural areas in Khmenlytskyi Oblast in Ukraine. The paper shows an anthropological perspective on the processes of social change and overcoming the effects of socialism in the sphere of mentality, attitudes and life orientations local communities.

Design/methodology/approach: Presented material refers to the empirical data obtained during fieldwork in the Khmelnytskyi region in 2018. The field study was conducted in three local communities in using ethnographic methods in order to analyze and describe the sociocultural effects of the political transformation that currently occur in rural areas. The research was based on the practical application of the concept of post-socialism and methodology developed by social anthropologists.

Findings: The question of rural areas development concerns the mobilization of local resources and given examples illustrate, that this process has already started in Ukraine. Local communities in rural areas are characterized by a "long duration", and therefore are relatively resistant to change. Communism legacy is an obstacle, hindering rebuilding subjectivity in former Soviet countries. Overcoming resentments connected with transition applies mainly to inhabitants of rural areas. The ongoing decentralization stimulates locality and social capital renewal.

Research limitations/implications: Rural areas in post-Soviet countries as a research area allow to observe both relics of the past and signs of social change. Conducted research made it possible to indicate the behaviors and attitudes characteristic of the previous system, as well as new practices establishing the foundations of civil society. Studies on rural areas development still require many in-depth qualitative and quantitative research.

Social implications: The interest in locality as a social phenomenon and a subject of analysis, has been changing. Return to the concept of locality in social sciences is related to the importance of locality in the process of social change - in that way locality becomes a dynamic and global problem associated with the activities of individuals, groups, institutions, policies and social processes.

Originality/value: Theoretical and empirical identification of interdependence between factors of "persistence" and "change" in selected local communities in rural areas in Khmenlytskyi Oblast.

Keywords: local community, rural areas, social change, social capital, Ukraine. 


\section{Introduction}

The processes of social change that have been taking place in Ukraine since twenty-eight years of its independence did not remain without an effect on rural areas, and this transformation had an influence not only on agriculture, but also on other forms of social life such as structure, labour market, local and regional identity or ecology issues. Analysing community development in post-Soviet Ukraine in the context of current political, economic and social processes and particularly the decentralisation reform, provides interesting conclusions on the processes of social change. Implementation of the decentralisation reform has been one the priority tasks of Volodymyr Groysman's government, intended at "promoting the development of local self-government and economic growth of country in general" (Decentralization.gov.ua, About Reform, para. 17). Decentralisation and local government reform are perceived as a milestone for democratization process in former Soviet states in order to overcome Soviet legacies, such as the administrative-territorial organization and the distribution of the responsibilities (Myshlovska, 2015, para. 4). With regard to the complex problems faced nowadays by inhabitants of rural areas, it becomes increasingly important to mobilize the resources of the local environment for self-development (Kaleta, 1998, p. 7). Apart from the experts' debates concerning barriers and limitations of the reform implementation, decentralisation has undoubtedly given the impulse for change, including the stimulation of social capital development.

The aim of this paper is to discuss the issues of locality and social capital revival as important factors of local and regional development of rural areas in Khmenlytskyi Oblast. Presented material refers to the empirical data obtained during fieldwork in the Khmelnytskyi region in $2018^{1}$.

\section{Main concepts definitions and methodological approach}

The issue of community development became an important field of research interest due to political, economic and social changes taking place in former Soviet countries. In case of rural areas, the process of transition has been much longer because of vicious consequences of the

\footnotetext{
${ }^{1}$ National Science Centre, Miniatura 1, „Persistence and change in the socio-cultural space of the contemporary Ukrainian village in the perspective of anthropology of postsocialism”, 2017. The field study was conducted in three local communities in Khmelnytskyi Oblast - Hrytsiv, Hannopil and Hwardijske - in order to analyze and describe the socio-cultural effects of the political transformation that currently occur in rural areas. Interviews were conducted with local authorities, activists, teachers, entrepreneurs, farmers, former kolkhoz workers, service workers. The following notations are assigned to the interviews: HR - Hrytsiv, HA - Hannopil, HW - Hwardijske. The number assigned refers to the order in which respondents were identified in a certain village. The quoted statements are marked in the text in italics.
} 
phenomenon, metaphorically called by Piotr Sztompka (2003) "the other side of transition" or "the trauma of a great change" (2003). Overwhelming post-Soviet inheritance concerns many aspects of social life in Ukraine, including (re)establishing of social capital potential and locality as a community philosophy. These two concepts, in the sociological perspective in particular, are perceived important factors of local and regional development. The question of stimulating local communities for activity is widely discussed in sociological literature (Kaleta, 1998; Gorlach et al., 2005; Weryński, 2010; Bukraba-Rylska et al., 2011; Rakowski, 2016). A variety of definitions of the concepts of locality and social capital, as well as the purpose of this study, make it essential to choose the most appropriate formula in the context of presented deliberations. Concerning the notion of social capital, for the purpose of this analysis an explanation suggested by Adam Bartoszek (2008) is used: "I assume that social capital should be perceived as a set of factors determining the ability to act, and not only as something objectified or reified in the form of a network of connections and structures. Social capital is then associated with cultural capital, and both have the form of a moral and competence resource resulting from the activity of people in social networks" (p. 74). In turn, locality is one of the most common descriptive and analytical categories in sociology (Majer, 2011, p. 27), strongly related to the community studies. Locality and local community both have "common Latin etymology localis, meaning a specific place or location; local therefore stand for assigned to a place" (Jałowiecki et al., 2007, p. 15). Methodological approaches, theories and concepts of locality are very diverse, nevertheless majority of them refer to the significance of location and space for establishing group identity and emotional connection. In the most common definitions of local community there are three types of components indicated: territorial (space), social (social bonds) and psychosocial (local identity) (Goszczyński, Knieć, \& Czachowski, 2015 , p. 11). The interest in locality as a social phenomenon and a subject of analysis, has been changing. Return to the concept of locality in social sciences, which took place in the $80 \mathrm{~s}$, is related to the importance of locality in the process of social change - in that way locality becomes a dynamic and global problem associated with the activities of individuals, groups, institutions, policies and social processes (Goszczyński, Knieć, \& Czachowski, 2015, p. 19, 20). In the spirit of these assumptions, local resources - as Weryński claims (2010) "are the residents' ability to organize and mobilize resources to achieve consensually agreed goals" (p. 164).

The study involved literature analysis and empirical data obtained during the field research conducted for the project "Persistence and change in the socio-cultural space of the contemporary Ukrainian village in the perspective of anthropology of postsocialism", financed by the National Science Center (2017). The project was aimed to identify and examine signs of post-Soviet patterns, attitudes and life orientations among inhabitants of three selected communities in rural areas in Khmelnytskyi Oblast (Synowiec, 2018). The research was based on the practical application of the concept of postsocialism and methodology developed by social anthropologists (Hann, 1985, 2004; Humphrey, 2004, Buchowski, 2001, 2017). The field 
study was conducted in three local communities - Hrytsiv, Hannopil and Hwardijske - in order to analyze and describe the socio-cultural effects of the political transformation in rural areas. The research was conducted between May and August 2018 using ethnographic methods; the collected research material includes 50 semi-structured and non-structured interviews and visual material.

\section{Ukrainian decentralisation reform as a context for locality and social capital revival}

The reform of local government in Ukraine was initiated by the political elites, who came to power after so-called Euromaidan revolution (2013-2014). As Rafał Czachor indicates (2017, p. 86), the reform of decentralisation "was conditioned by internal as well as external factors, such as local government responsibilities in the system of power, Ukraine's commitments towards European Union and Minsk agreements" (a roadmap designed to solve a conflict over Donbas). The implementation of the reform was aimed at achieving three objectives: 1) to improve the mechanisms of governance; 2) to guarantee the territorial integrity and strengthen periphery; 3) to legitimize "the western choice of Ukraine" (Czachor, 2017, p. 86). Territorial communities unite as a result of the voluntary association of neighbouring territorial units, such as villages, settlements, and cities and become amalgamated territorial communities (ATC) or amalgamated hromadas (AH). "As of the beginning of February 2019, 878 amalgamated territorial communities (the "ATCs") were already established. Those ATCs are composed of about 4,018 former local councils. Currently, 9 million people reside in the ATCs" (Dentralization.gov.ua, About Reform, para. 11). The process of territorial communities consolidation is perceived as efficient. The Minister of Regional Development, Construction, Housing and Communal Services of Ukraine, Hennadii Zubko, commented on the reform monitoring in May 2019: "The amalgamation process is underway. Thirty three cities of oblast significance have already merged with neighbouring hromadas. The top five regions in the decentralisation process remain unchanged. The Zhytomyr, Chernihiv, Zaporizhzhia, Dnipropetrovsk and Khmelnytskyi Oblasts continue to be the top-performers in establishing capable hromadas" (Decentralization.gov.ua, 14.05.2019, para. 2). Currently in the Khmelnytskyi Oblast there are 47 ATCs, covering over 58\% of the territory of the entire region, what gives Khmelnytskyi Oblast the fifth position behind Zhytomyr (55 ATCs), Dnipropetrovsk (62), Volyn (51) and Zaporizhzhia (48). According to experts, one of the main obstacles disrupting the local government reform in Ukraine are of a structural nature: "There is still a lack of understanding of the idea of self-governance among a large part of society. After more than half a century of Ukrainian SSR ruled by communists and years of an independent, but centralized and oligarchic Ukraine, local communities (...) lack the sense 
of responsibility for their own village or city, and still there is a common consent for corruption and combining public posts with business activities development" (The Polish Institute of International Affairs Bulletin, No. 16, 12/02/2015). Along with the Soviet Union collapse, Ukraine has entered the transition phase. Paul R. Magosci in monumental history of Ukraine notes, that while "for several central European countries the transition period could be said to have ended on the eve of their entry to the European Union between 2004 and 2007" (2010, p. 726), for Ukraine it has been still continued.

The slowdown of transition process in Ukraine is caused by economic, political and social factors. With regard to rural communities, the main development barriers result from the decline in production and, as a consequence, workplaces reduction, that mainly affected the areas where one production sector dominated. This led to the emergence of unemployment and decrease of revenues in local governments' budgets, and caused in the deterioration and even degradation of social and road infrastructure. Last, but not least is depopulation of rural areas - as estimated, every year, the rural population of Ukraine is reduced by 147 thousand people; the number of villages decreases as well: for the period from 1990 to 2017, 468 villages disappeared from the map of Ukraine, that is, an average of 18 villages annually (Agroportal.ua, 12.04.2019, para. 1). Since 1991, Ukrainian agriculture has been exposed to serious upheaval, including the loss of traditional markets, deterioration of trade conditions, limited access to international loans (World Bank Report, 1994). On the other hand, the position of the agricultural sector in the structure of the national economy is very strong: in 2013, the share of agriculture in Ukraine's GDP was 9\% (Lopatynskyi, 2016, p. 28), while in 2018 it increased to 10.1\% (World Bank Indicators, 09.10.2018). According to the statistics of the International Labour Organization, the employment rate in agriculture reaches $16.52 \%$ among man and $13.16 \%$ among women (ILOSTAT Database, September 2018 for: World Bank Indicators, 10.09.2018). Besides, as Danny Hakim - reporter of The New York Times - remarks "Ukraine was once the breadbasket of the Soviet Union, (...). Production is only now returning to peak levels of the 1990s, stymied by the corruption, red tape and inefficiencies that have plagued the broader Ukrainian economy for years and left the villagers living humble existences" (Hakim, 2014, para. 4). Polish sociologist of rural studies, Andrzej Kaleta (1998) emphasizes that resolving multidimensional crisis that affects mainly small towns and villages, "requires counteraction from the local community as a group of people who are naturally and originally associated with the area, understanding its needs and development opportunities" (p. 11).

Firstly, decentralisation reform in Ukraine responds to the fundamental necessity of changing the prior structure of power at all levels, in order to enable country's development. Secondly, decentralisation provides substantive and financial assistance for intensified work with the communities, encouraging for economic, cultural and educational development through their own initiatives. Rural communities, likewise, face up to challenges related to the change of perspective on the local community organization. Such a way of thinking, refers to the following issues: 1) how to combine the efforts of the state, nongovernmental organizations 
and socially responsible business for the more efficient development of rural areas?; 2) how can rural areas be developed by means of community resources and internal initiatives?; 3) what can be learnt from the best practices from other countries? Achieving success in this area requires, without doubt, the revival of social resources. According to Sztompka (2016) social subjectivity - "the motive force for social change" - is being produced in the network of interpersonal relations (p. 32). In the globalized world, the importance of local communities has been increasing. For post-Soviet countries it means overcoming communist legacies in terms of (re)establishing subjectivity and agency. The issues of locality and social capital restoration cannot be missed in the discussion about local and regional development of rural areas.

\section{Building potential of rural areas in the Khmelnytskyi region on the example of Hrytsiv community}

The problem of countryside revival and rural areas development due to mobilization of local resources is connected with deep internal conflict concerning the concept of the countryside itself and its perception. On the one hand, in social consciousness countryside equates all features of periphery, and hence all the features that are associated with backwardness, marginality, poverty and oblivion. Such a picture of rural areas, as a remorse, contradicts theories of modernization and transition prizes. Although, in Ukrainian context, countryside is subjected to strong mythologization: it is perceived as the cradle of the nation and the basis for establishing community. Countryside in this case serves as a source of symbolic capital for the construction of Ukrainian identity, through strong association of people with the nation (Synowiec, 2013). Employing social concept of countryside as a core of common origin, related to preserving folk (in the meaning of national) traditions or an image of idyllic rural life allows to build a very spacious category of "we". Therefore the relevance of the question of rural areas development becomes more and more vivid. A metaphor of "moving away from the paradigm of survival towards the paradigm of creativity", used by one of the interviewees, illustrates perfectly the increasing necessity of finding a solution for rural areas development. The process of social change in Ukrainian countryside in no longer only an "escape from socialism" (Buchowski, 2001, p. 9) - high level of reflection of many interlocutors shows the willingness to go beyond agriculture, to popularize green tourism, ecology issues, historical-cultural heritage and countryside itself.

Khmelnytskyi Oblast is one of the least urbanized regions of Ukraine: the priority branches of economy are agriculture, food industry, energy industry, mechanical engineering and production of building materials (Strategy for Regional Development of the Khmelnytskyi Oblast, 2011-2020, p. 26). The percentage of the rural population is $42.48 \%$ (State Statistics 
Service of Ukraine, 01.01.2019). Rural areas of Khmelnytskyi Oblast display a number of features typical for periphery: population decline, agriculture as dominant economy sector, accompanied by poor communal and road infrastructure. Andrzej Kaleta (1998) underlines, that the issue of local communities mobilization in rural areas is closely connected with development, understood as establishing living conditions that respond both to material and spiritual aspect of life (p. 7). However, one comment about the infrastructure conditions collected in Hrytsiv is worth quoting here: It is not about the road, the road it is not the main problem, it can be fixed sooner or later. But the new road won't replace the changes in thinking about countryside [HR_1]. Socio-economic studies concerning question of peripheral areas development emphasize the significance of internal potential: “(...) insufficient human and social capital resources do not allow for the initiation of socio-economic development processes to establish a correct trajectory to development and to ensure the appropriate use of economic resources" (Guzal-Dec, \& Zwolińska-Ligaj, 2017, p. 98). The following section presents examples of building rural areas potential making use of local resources, referring essentially to Hrytsiv's case.

Hrytsiv is the administrative centre of Hrytsiv ATC, the settlement has 3534 inhabitants, the number of people living on the territory of hromada is 8602. In Hrytsiv there are no large farms or agricultural cooperatives. Residents find employment mainly in the Polish-Italian sewing room (about 300 people), in the public sector (employees of education and culture) and in trade and services. Hrytsiv is not an exclusion while taking into account the labour migration: many people go to work - temporarily or permanently - and this phenomenon applies to Ukraine in general. Hrytsiv is a very interesting community not only on regional scale: it was in Hrytsiv, where rural development program supported by Agriculture Cooperative Development International was launched and where, since 2005, volunteers from the US Peace Corps came to help local NGOs to increase their potential. The main task of volunteers was to involve the local community in activities residents would like to do: (...) These could have been school projects. They were looking for programs allowing young people for example to go to study, to go for a seminar. Find out what people here could do, what their needs are-and later create a program to develop this place [HR_5]. Residents began to develop green tourism and established a cluster "Oberig" (which means amulet), associating several green farms. However, it should be noted that Hrytsiv is distant from tourist attractions - green tourism in Khmenytskyi Oblast is well developed mainly in places with historical or environmental attractions, such as Kamianets-Podilskyi, Khotyn or Bakota. Investing in agritourism allowed entrepreneurs to look more broadly and understand the need to improve living standards in premises, because otherwise tourists will not come: I quickly understood that the better the conditions I can offer, the more people will come and I will earn more money. I invest my money in improving conditions [HR_5]. 
There are two nongovernmental organizations in Hrytsiv: one is oriented on sharing and implementing sustainable development principles; the second one is focused on supporting changes in local community performing as community fund: We help those who want to change the surroundings around them. If someone writes a project, we are looking for resources to implement these projects. This is a place where people gather those, who have ideas and donors, who are ready to help financially [HR_8]. The extraordinary activity of local leaders and the development of their competences allowed for reaching for foreign sources of financing - for example Eurasia Foundation. The obtained funds helped to support small local groups that wanted to implement projects related to the social and economic development of the territorial community. The success of the "Mini-projects program" has initiated a long-term cooperation with the Eurasia Foundation. Later, the program supporting mini-projects was repeated with funding from the Stefan Batory Foundation. In turn, this cooperation resulted in the next project "Fund for supporting local initiatives", which was aimed to establish the basis for the development of local stakeholders partnership. The Association "Hrytsiv Revival" has started organizing local festival, that have undoubtedly contributed to the locality renewal. This festival is something that can connect people, or help them to connect [HR_8]. The main goal of the festival is to popularize the idea of community unity, folk traditions and the cultural and historical heritage of the region.

Both NGO's are targeted on supporting the socio-economic development of the community, the renewal of cultural traditions and mobilizing the local resources. One of the initiatives is particularly interesting: since 2000, in the former property of Grocholski family, which has been transformed for vocational school premises, a culture event has been organized each year. From 1752 Hrytsiv belonged to the Grocholski house; Michał Grocholski built there a palace, which - like many others - after the October Revolution was nationalized and assigned for different purposes, e.g. for the local committee of communism party premises. The "Old Volhynia Bal" draws upon historic tradition of balls: this certain type of event is aimed at restoring memory of the place and its' past, building awareness of cultural heritage and integration of the local community. It is necessary to show people where they come from and what are their roots. It is essential for completing transition in rural areas. Culture has been wiped out from here for over 70 years, and we need to restore it to make the real transition of rural areas happen [HR_16]. Sustainable Development Fund "Old Volhynia" makes many efforts to help local communities define their own shape. According to "Old Volhynia" activists, the most important thing to do in order to develop rural areas is to find innovative solutions to create appropriate conditions in social, cultural and spiritual spheres. In their opinion culture and subjectivity are crucial for contemporary Ukrainian countryside. Thus they organize seminars and workshops indicated on training leader skills and preparing youth to work with local communities in rural areas. In 2018 "Old Vohynia" with a support of donors launched a project called "The Lost Community" - thematic educational summer camp for pupils and students from Khmelnytskyi Oblast oriented to teach future community leaders. 
Participants settle their "community", try to survive in difficult conditions, develop soft skills, define assets etc. For the successful implementation of decentralization reform, we need first of all a network of new leaders, who are able to act effectively and professionally in the interests of the community, sustainable regional development and strengthening of the state [HR_16]. According to local leaders, community development can be done in two ways. The first direction is solving problems through mini-grants competition or other type of financing. The second one is the analysis of possibilities, potential and putting resources into this potential, in possibilities, that is, creating something new [HR_8]. Local leaders demonstrate great commitment in the activities undertaken. They can be called "carriers of change": they seek new solutions, undertake difficult challenges, inspire others, encourage them to join in activities for the community. Finally, they engage young people and involve them in numerous projects. The syndrome of post-communist legacy remains in attitudes of obedience and subordination. Local community leaders want to overcome this symptoms and help local residents to become to more independent and active. Conscious participation in the life of the rural community becomes a resource and capital for the emergence of a future civil society.

\section{Conclusions}

Ukrainian rural areas have been struggling with a set of problems requiring solutions, ranging from living conditions improvement, through issues related to the protection of the natural environment and cultural heritage, to the issue of social involvement and a change of approach in thinking about the organization of the local community. "According to many researchers, local communities are the main subject and animator of a particular process of change, called local or endogenous development, because the role of intra-system factors is emphasized in there (...)" (Jałowiecki, \& Szczepański, 2002, p. 19). All these small communities are part of the overall picture of Ukraine's life. Maybe small communities are not very "visible", but they are crucial for the integrity and stability of Ukraine as an independent country with its own identity and competitive economy [HR_1]. The question of rural areas development concerns the mobilization of local resources and the example of Hrytsiv illustrates, that this process has already started in Ukraine. Local communities in rural areas are characterized by a "long duration", and therefore are relatively resistant to change (Jałowiecki, \& Szczepański, 2002, p. 98). Undoubtedly, communism legacy is an obstacle, hindering rebuilding subjectivity in former Soviet countries. Overcoming resentments connected with transition applies mainly to inhabitants of rural areas. Nevertheless, the ongoing decentralization stimulates locality and social capital renewal. 


\section{References}

1. Agroportal.ua, 18.05.2018. Available online: http://agroportal.ua/publishing/konkurs/ vopros-mesyatsa-pochemu-vazhno-razvivat-ukrainskoe-selo/, 15.07.2019.

2. Bartoszek, A. (2008). Konwersja kapitałów społeczno-kulturowych na kapitał obywatelski - rzecz o wytwarzaniu otwartych społeczności. In: M.S. Szczepański, K. Bierwiaczonek, T. Nawrocki (Eds.), Kapitały ludzkie i społeczne a konkurencyjność regionów (pp. 74-86). Katowice: Wydawnictwo Uniwersytetu Śląskiego.

3. Buchowski, M. (2001). Transformation. An anthropological perspective on post-socialism. Poznań: Humaniora.

4. Buchowski, M. (2017). Czyściec. Antropologia neoliberalnego postsocjalizmu. Poznań: Wydawnictwo Naukowe im. Adama Mickiewicza.

5. Czachor, R. (2017). Wyzwania reformy samorządowej i procesu decentralizacji na Ukrainie po 1991 roku. Przegląd Wschodnioeuropejski, VIII/1, pp. 79-90.

6. Decentralization.gov.ua Available online: https://decentralization.gov.ua/en/, 15.07.2019.

7. Gorlach, K., Foryś, G. (Eds.) (2005). W obliczu zmiany: wybrane strategie działania mieszkańców polskiej wsi. Kraków: Wydawnictwo Uniwersytetu Jagiellońskiego.

8. Goszczyński, W., Knieć, W., Czachowski, H. (2015). Lokalne horyzonty zdarzeń. Lokalność $i$ kapitał społeczny $w$ kulturze (nie)ufności na przykładzie wsi kujawskopomorskiej. Torun: Muzeum Etnograficzne w Toruniu.

9. Guzal-Dec, D., Zwolińska-Ligaj, M. (2017). The Role of Local Action Groups in the Process of Multifunctional Development of a Peripheral Region. A Case Study of the Region of Lublin, Poland. Wieś i Rolnictwo, 3(176), pp. 97-120, doi: 10.7366/ wir032017/05.

10. Hakim, D. (2014). Ukraine Faces Hurdless in Restoring Its Farming Legacy. The New York Times, Retrieved from https://www.nytimes.com/2014/05/28/business/ukraine-faceshurdles-in-restoring-its-farming-legacy.html, 15.07.2019.

11. Humphrey, C. (2004). Does the category 'postsocialist' still make sense? In: C.M. Hann (Eds.), Postsocialism. Ideals, ideologies and practices in Eurasia. New York: Routlegde.

12. Jałowiecki, B., Szczepański, M.S. (2002). Rozwój lokalny i regionalny $w$ perspektywie socjologicznej. Tychy: Śląskie Wydawnictwa Naukowe WSZiNS.

13. Jałowiecki, B., Szczepański, M.S., Gorzelak, G. (2007). Rozwój lokalny i regionalny w perspektywie socjologicznej. Tychy: Śląskie Wydawnictwa Naukowe WSZiNS.

14. Kaleta, A. (1998). Rewitalizacja obszarów rustykalnych. Tom III: Aktywizacja społeczności lokalnych. Wrocław-Warszawa-Kraków: Zakład Narodowy im. Ossolińskich.

15. Kołodziejska, M., Hnatiuk, M. (2015). Pożegnanie z homo sovieticus: próba empirycznej weryfikacji kategorii oraz analiza jej obecności w dyskursie o transformacji. In: P. Sadura, 
M. Gdula (Eds.), Style życia i porządek klasowy w Polsce. Warszawa: Wydawnictwo Naukowe Scholar.

16. Łopatynskyi, Y.M. (2016). Zrównoważony rozwój sektora rolnego na Ukrainie w kontekście strategii Europa 2020. Gospodarka w praktyce i teorii, 1(42), pp. 27-28.

17. Magosci, P.R. (2010). A History of Ukraine: The Land and Its People. University of Toronto Press.

18. Majer, A. (2011). Lokalność w cieniu globalizacji. Annales Universitatis Mariae CurieSkłodowska, XXXVI, 2, pp. 27-46.

19. Myshlovska, O. (2015). Democratising Ukraine by Promoting Decentralisation? A Study of Swiss-Ukraine Cooperation "International Development Policy" [online]. Retrieved from: http://journals.openedition.org/poldev/2010, 15.07.2019.

20. Państwowy Komitet Statystyki Ukrainy: Populacja Ukrainy stan z 01.01.2019. Retrieved from: http://www.ukrstat.gov.ua, 05.07.2019.

21. Rakowski, T. (2016). Działania edukacyjne w przestrzeniach wsi. Odkrywanie podmiotowości środowisk wiejskich. In: K. Kojder, E. Pajestka (Eds.), Nasze miejsce. Inspirator do pracy z lokalnością. Warszawa: Stowarzyszenie „Pracownia Etnograficzna” im. W. Dynowskiego.

22. Skorupska, A., Kościński, P. (12.02.2015). Ukraina. Reforma administracyjna przyśpiesza powoli. Biuletyn Polskiego Instytutu Spraw Międzynarodowych, 16/1253. Retrieved from: https://www.pism.pl/publikacje/biuletyn/nr-16-1253, 15.07.2019.

23. Strategia Rozwoju Regionalnego Obwodu Chmielnickiego 2011-2020 (2011). Retrieved from: http://www.adm.km.ua/doc/doc37_RD_Strategy.pdf.

24. Synowiec, A. (2013). Przejawy strategii tożsamościowych w znakowaniu terytorium. Lwów jako przestrzeń emblematyzacji. In: L. Dyczewski, K. Kurek (Eds.), Rzeczywistość wielokulturowa, t. 8. Tożsamość osób, zbiorowości i instytucji. Lublin: Wydawnictwo Katolickiego Uniwersytetu Lubelskiego.

25. Synowiec A. (Ed.) (2018). Trwanie $i$ zmiana $w$ przestrzeni społeczno-kulturowej współczesnej ukraińskiej wsi. Refleksje z badań terenowych. Gliwice: Wydawnictwo Politechniki Śląskiej.

26. Sztompka, P. (2003). Trauma kulturowa. Druga strona zmiany społecznej. In: A. Kojder, K.Z. Sowa (Eds.), Los $i$ wybór. Dziedzictwo i perspektywy społeczeństwa polskiego. Pamiętnik XI Ogólnopolskiego Zjazdu Socjologicznego. Rzeszów: Wydawnictwo Uniwersytetu Rzeszowskiego.

27. Sztompka, P. (2016). Kapitał społeczny. Fundament społeczeństwa. Kraków: Znak.

28. Weryński, P. (2010). Wzory uczestnictwa obywatelskiego Polaków. Warszawa: Wydawnictwo IFiS PAN.

29. World Bank Indicators. Retrieved from https://data.worldbank.org/indicator/ NV.AGR.TOTL.ZS?view=chart, 15.07.2019. 